\title{
SYNTHESIS, CHARACTERIZATION AND BIOLOGICAL EVALUATION OF SOME NOVELTHIAZOL DERIVATIVES OF N-((2-CHLOROPHENYL)DIPHENYLMETHYL)-4-PHENYLTHIAZOL-2-AMINE
}

\author{
Krishna K. Limbasiya**1, Jayesh Babariya ${ }^{2}$, Krushnakumar J. Jilariya ${ }^{3}$, V. A. Modhavadiya ${ }^{1}$ \\ ${ }^{l}$ Department of Chemistry, M. M. Science College, Morbi, Gujarat, India \\ ${ }^{2} H$. N. Shukla group of College, Rajkot, Gujarat, India \\ ${ }^{3}$ SMT. J.A. Patel Mahila College, Patel Kanya Chhatralaya Campus, Morbi, Gujarat, India \\ *Corresponding author: jayeshbabariya50@gmail.com
}

\begin{abstract}
In present work we synthesized novel series of thiazole derivatives of N-((2-chlorophenyl)diphenylmethyl)-4phenylthiazol-2-amine in the presence of dichloromethane and triethylamine in good yield. The different studies indicate that newly synthesized compounds possess moderate to good biological activities. The title compounds have been synthesized with several structural variations. Biological evaluation of all the synthesized compounds has been carried out in vitro for their antibacterial and antifungal efficacy against various bacterial and fungal strains. The structure of synthesized compounds were characterized by their spectral (IR, ${ }^{1} \mathrm{H}$ NMR and Mass) data.
\end{abstract}

Keywords: Thiazol, Dichloromethane, Triethylamine, Biological evaluation.

\section{INTRODUCTION}

The thiazole has an essential component effect of the pharmacophores of a great number of medicinal importance molecules and the evaluation of their biological activity, such as antibacterial [1], antiprotozoal [2], antitubercular [3], antifungal [4, 5], and anthelmintic [6], with emphasis on their potential medicinal applications, is desirable. Here we are interested to study newly synthetized aminothiazoles, especially 2-aminothiazole derivatives which represent a class of heterocyclic ring system possessing antiviral [7], antimi-crobial [8], anticancer [9], and anti-inflammatory activities [10]. Previously, in vitro anticancer evaluation studies of different 2-aminothiazole analogs exhibited their potent and selective nanomolar inhibitory activity against a wide range of human cancerous cell lines such as breast, leukemia, lung, colon, CNS, melanoma, ovarian, renal, and prostate cell lines [11-14]. Substitutions at 2-position benzothiazole have emerged in its usage as a core structure in the diversified therapeutic applications [15-21]. The studies of structure- activity relationship interestingly reveal that change of the structure of substituent group at $\mathrm{C}-2$ position usually results in the change of its bioactivity. Though literature survey reports many therapeutic applications of 2-substituted benzothiazoles, their investigation for anti-inflammatory activity is limited
[16, 22-25]. Furthermore, thiazole derivatives have attracted a great deal of interest due to their wide applications in the field of pharmaceuticals.

Because of the very high growth of drug resistance against the existing antibacterial and antifungal drugs, there is a crucial need of synthesis of privileged classes of heterocyclic compounds in the field of synthetic and medicinal chemistry. In spite of numerous significant progresses in the antimicrobial therapy, diseases which are very infectious caused by bacteria and fungi remain a very big worldwide issue. Multi drug resistance (MDR) is an antimicrobial resistance shown by a family of microorganisms to multiple antimicrobial drugs. In specific, the emergence of multidrug resistant strains of gram-positive bacterial pathogens such as methicillin resistant Staphylococcus aureus and Staphylococcus epidermis and Vancomycin-resistant enterococcus are problem of ever-increasing importance. Multi drug resistance tuberculosis is a type of tuberculosis which occurs when the bacteria are resistant to the most powerful anti TB drugs called Isoniazid and Rifampin. Mycobacterium tuberculosis is a bacteria which is responsible for the contagious disease called as tuberculosis. Generally, it affects the lungs of the body and called as pulmonary $\mathrm{TB}$, but in few cases, it can also affect other parts of the body and called as extra pulmonary TB. The authoritative symptoms of tuberculosis are fever, night 
sweats, blood containing sputum, etc. Drug resistance emerges when anti-TB medicines are used inappropriately, through incorrect prescription by health care providers, poor quality drugs, and patients stopping treatment prematurely. MDR-TB is treatable and curable by using second- line drugs. Poor chemotherapeutics and inadequate local control programme are the two major causes that it is not possible to manage TB and thus leads to the emergence of drug resistant strains of MTB. Drug resistant TB is very difficult to cure. It takes 18-20 months, if the patient is responsive to the second line treatment regimen in a positive manner. This regimen is very costly to treat in comparison to fully drug sensitive TB. Presently, available second line drugs are not very effective and moreover, cause side effects and therefore it is necessary to identify novel drug targets. Thiazole derivatives display a wide range of biological activities such as cardiotonic, fungicidal, sedative, anesthetic, bactericidal, and anti-inflammatory [26, 27]. In addition, thiazole derivatives are reported to show a variety of biological activities. Depending on the substituents, this heterocycle possesses anthelmintic, antibiotic, and immunosuppressant activity [28]. Recent researches indicate that some of 2-aminothiazoles derivatives are inhibitors of enzymes such as kynurenine-3- hydroxylase or possess inhibitors activity against enzyme cyclin-dependent kinase [29].

In the existing work, we report the synthesis of this novel series of thiazole derivatives of $\mathrm{N}-((2-$ chlorophenyl)diphenylmethyl)-4-phenylthiazol-2-amine and biological evaluation of all the synthesized compounds have been carried out in vitro for their antibacterial and antifungal efficacy against various bacterial and fungal strains. The main significance of the work is that it will provide synthesized and additional potent stable molecule for biological response as most of thiazole derivatives have significant biological activity. As we mentioned above, the significance and biological profile of this class of molecule so our continue efforts towards the synthesis of potential heterocyclic molecules.

\section{EXPERIMENTAL}

All chemicals and solvents used to the synthesised library were purchased from $\mathrm{CDH}$ chemical, Delhi of AR grade and were used without further purification. Reactions were monitored by thin-layer chromatography (TLC) on silica gel-G plates (G60 F254 (Merck)) of $0.5 \mathrm{~mm}$ thickness, visualization was done with ultraviolet light (254 and $365 \mathrm{~nm}$ ), or with iodine vapour chamber and aq. $\mathrm{KMnO}_{4}$ reagent. Melting points were taken in open capillary and are uncorrected. IR spectra were recorded on FTIR-8400 spectrophotometer (Shimadzu, Kyoto, Japan), using DRS probe $\mathrm{KBr}$ pallet. ${ }^{1} \mathrm{H}$-NMR spectra of the synthesized compounds were recorded on a Bruker-Avance-II (400 $\mathrm{MHz}$ ) DMSO solvent.

Chemical shifts are expressed in $\delta$ ppm downfield from TMS as an internal standard. Mass spectra were determined using a direct inlet probe on a GCMS-QP 2010 mass spectrometer (Shimadzu, Kyoto, Japan). Physical constants of the synthesized compounds are shown in Table 1.

\subsection{General synthesis method for (2-chloro- phenyl)diphenylmethanol (INT-01)}

Bromobenzene $(1.6 \mathrm{~g}, 10.5 \mathrm{mmol})$ was added to magnesium turnings $(0.25 \mathrm{~g}, 10.5 \mathrm{mmol})$. The reaction mixture was stirred at reflux and then at room temperature for further 6 hours. (2-chlorophenyl) (phenyl)methanone $(1.5 \mathrm{~g}, 7 \mathrm{mmol})$ was added and the reaction mixture was left stirring at room temperature for overnight. The reaction mixture was quenched with saturated ammonium chloride solution $(30 \mathrm{~mL})$. The aqueous layer was separated. Combined organic layers were washed with water and dried over $\mathrm{MgSO}_{4}$ and then removed. The crude yellow oily mass obtained was purified by flash chromatography to give $0.75 \mathrm{~g}$ of alcohol (2) (36\% yield) as white crystals ( $\left.\mathrm{mp} 83-85^{\circ} \mathrm{C}\right)$.

\subsection{General synthesis method for (chloro(2- chlorophenyl)methylene)dibenzene(INT-2)}

Thionyl chloride $(0.82 \mathrm{~g}, 6.9 \mathrm{mmol})$ was added into a solution of (2-chlorophenyl)diphenylmethanol (INT-01) $(0.69 \mathrm{~g}, 2.3 \mathrm{mmol})$ and the mixture was stirred at $0^{\circ} \mathrm{C}$ for 1 hour. The reaction mixture was left at reflux stirring for overnight. The organic solvent was evaporated and the residue was washed with acetonitrile $(2 \times 20 \mathrm{~mL})$ to afford compound (3) as a solid.

\subsection{General synthesis method for $\mathrm{N}-((2-$ chlorophenyl)diphenylmethyl)-4-phenyl- thiazol-2-amine (KJB-01 TO KJB-10)}

Into a $100 \mathrm{ml} \mathrm{RBF}$, Dichloromethane was taken and stirred at RT. (chloro(2-chlorophenyl)methylene) dibenzene (INT-2) was added in a on slot and further stirred for $10 \mathrm{~min}$ to ensure clear solution. Previously prepared different substituted 4-phenylthiazol-2-amine was added to the reaction mixture in one slot followed 
by addition of tritely amine to the reaction mixture to quince $\mathrm{HCl}$ which was generated during the reaction. After completion of the reaction, reaction mixture was poured in to cooled water and organic layer was separated. Combined organic layer was evaporated to yield crude product. Crude product was purified by column chromatography using ethyl acetate and hexane solvent system. Compound was eluted at $1 \%$ ethyl acetate: 99\% Hexane system.

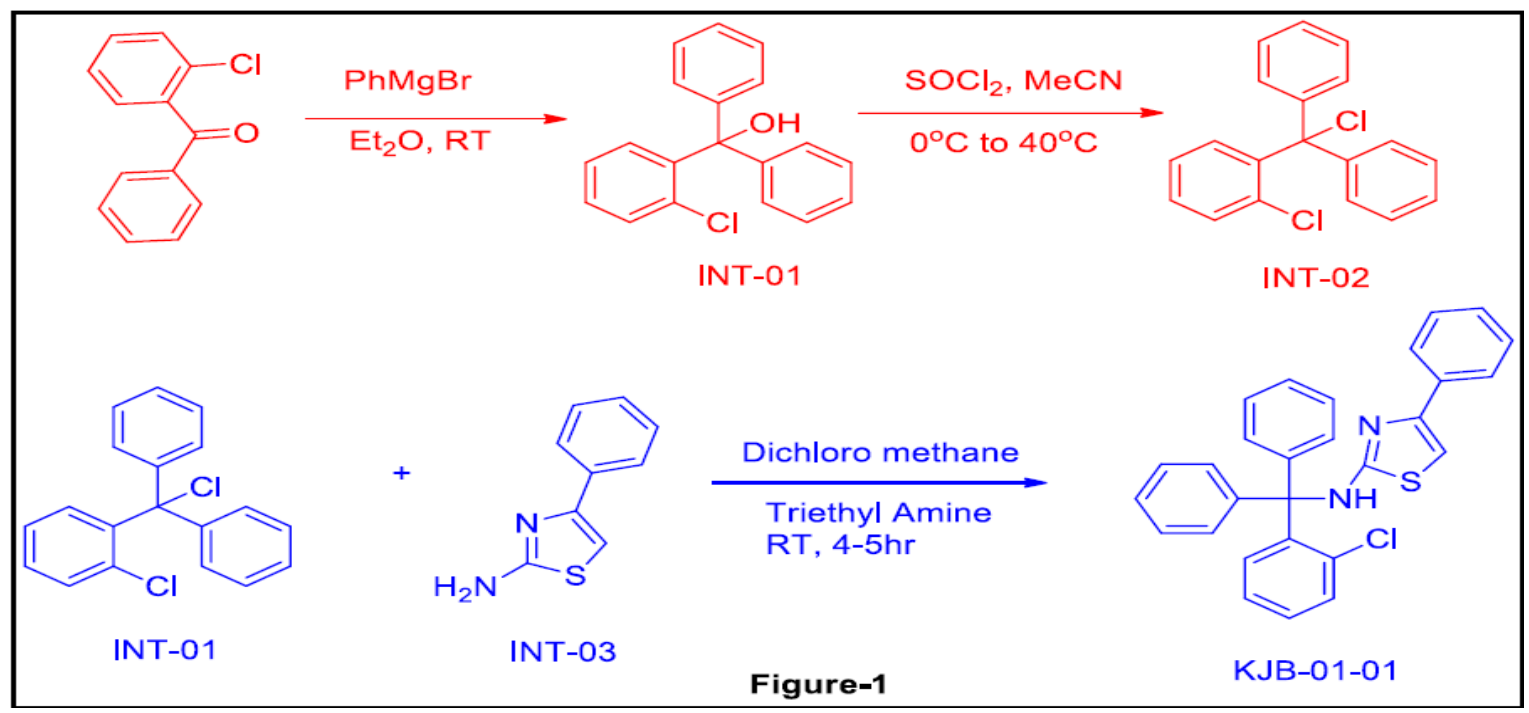

Fig. 1: Reaction Scheme

\subsection{Biological Evaluation}

In our existing study antibacterial and antifungal activity were tested by standard agar cup method. All the synthesized compound were tested for their in vitro antimicrobial activity against Gram $+_{v e}$ (Bacillus megaterium, Micrococcus spp.), Gram -ve (E.coli, S. typi) and fungal spps. (Ganoderma spp., A. niger, A. flavus and Penicillium spp.), taking streptomycin, ciprofloxacin, and nystatin as standard drugs. Suspension of 24 to $48 \mathrm{hrs}$ grown fresh bacterial and fungal culture was prepared in $\mathrm{N}$-broth and potato dextrose broth respectively. All the bacterial and fungal suspension were equally spread on to the sterile Muller Hinton and PDA plates respectively with the help of sterile swabs. Wells were made in the plates $(1 \mathrm{~cm})$ with the help of sterile cork borer. The standard antibiotics were dissolved in sterile distilled water to make the final concentration of $200 \mu \mathrm{g} / \mathrm{ml}$. The synthesized compounds to be tested were dissolved in DMSO up to the final concentration of $1 \mathrm{mg} / \mathrm{ml}$ and $0.1 \mathrm{ml}$ of it was loaded in the well. The plate was incubated at $4{ }^{\circ} \mathrm{C}$ for 20 minutes for proper diffusion of a compound in agar and then the plates were incubated in the upward position for $24 \mathrm{hrs}$ at $37^{\circ} \mathrm{C}$ for bacterial culture and $48 \mathrm{hrs}$. at $25^{\circ} \mathrm{C}$ for fungal cultures. The control activity against DMSO was also performed. After incubation zone of inhibition was observed and measured.

\section{RESULTS AND DISCUSSION}

\subsection{Synthesis and structural characterization}

We have prepared a series of novel thiazol derivatives of $\mathrm{N}$-((2-chlorophenyl)diphenylmethyl)-4-phenylthiazol-2amine which is showed in Fig. 1.

Initial analogue (chloro(2-chlorophenyl)methylene) dibenzene was synthesized from (2-chlorophenyl) diphenylmethanol. During final step of reaction, 4-phenylthiazol-2-amine reacts with (chloro(2-chlorophenyl)methylene)dibenzene with nucleophilic substitution reaction in presence of dichloromethane and triethylamine in good yield compounds are synthesized scuessfully. All the steps are shown in fig. 1.On the basis of IR spectra, amide $\mathrm{C}=\mathrm{O}$ stretching frequency was observed at $1640 \mathrm{~cm}^{-1}$ which indicates presence of amide functional group. On the other hand, different types of carbon skeleton with types of hydrogen were confirmed by ${ }^{1} \mathrm{H}$ NMR spectra. Therefore structures of all the synthesized compounds were confirmed by IR, NMR and Mass spectroscopy.

\subsection{Spectral data of synthesized compounds 3.2.1. N-((2-chlorophenyl) diphenylmethyl)-4- phenylthiazol-2-amine(KJB-1)}

Yellow Solid, Rf value 0.42 (Ethyl acetate 8: Hexane 2). IR (KBr pallet) in $\mathrm{cm}^{-1}: 3179,3042,2887,2795,2706$, 1510, 1390, 1329, 1272, 1173, 1077, 1025, 913, 847, 
$745,699 \mathrm{~cm}^{-1} .{ }^{1} \mathrm{H}$ NMR (DMSO) in $\delta \mathrm{ppm}: 6.54$ to 7.70 (20H, Complex), 1.26 (1H, Singlet broad). Mass $(\mathrm{m} / \mathrm{z})$ : 452. Ana. Calculated for Molecular formula $\mathrm{C}_{28} \mathrm{H}_{21} \mathrm{ClN}_{2} \mathrm{~S}$ is $\mathrm{C} ; 74.24 \%, \mathrm{H} ; 4.67 \%, \mathrm{~N} ; 6.18 \%$ Found C; $74.22 \%, \mathrm{H} ; 4.65 \%, \mathrm{~N} ; 6.12 \%$.

\subsubsection{4-(4-chlorophenyl)-N-((2-chlorophenyl) diphenylmethyl) thiazol-2-amine(KJB-2)}

Yellow Solid, Rf value 0.46 (Ethyl acetate 8: Hexane 2). IR ( $\mathrm{KBr}$ pallet) in $\mathrm{cm}^{-1}: 3172$, 3040, 2885, 2792, 2708, 1512, 1392, 1328, 1274, 1175, 1078, 1026, 912, 847, $746,698 \mathrm{~cm}^{-1} .{ }^{1} \mathrm{H}$ NMR (DMSO) in $\delta \mathrm{ppm}: 6.85$ to 7.54 (19H, Complex), 6.44 (1H, Singlet broad). Mass $(\mathrm{m} / \mathrm{z})$ : 486. Ana. Calculated for Molecular formula $\mathrm{C}_{28} \mathrm{H}_{20} \mathrm{Cl}_{2} \mathrm{~N}_{2} \mathrm{~S}$ is $\mathrm{C} ; 68.99 \%, \mathrm{H} ; 4.14 \%, \mathrm{~N} ; 5.75 \%$ Found $\mathrm{C} ; 68.90 \%, \mathrm{H} ; 4.12 \%, \mathrm{~N} ; 5.72 \%$.

\subsubsection{4-(4-bromophenyl)-N-((2-chlorophenyl) diphenylmethyl)thiazol-2-amine (KJB-3)}

Yellow Solid, Rf value 0.48 (Ethyl acetate 8: Hexane 2). IR (KBr pallet) in $\mathrm{cm}^{-1}$ : 3166, 3025, 2886, 2791, 2709, 1516, 1394, 1329, 1270, 1178, 1079, 1027, 911, 845, $744,697 \mathrm{~cm}^{-1}$. ${ }^{1} \mathrm{H}$ NMR (DMSO) in $\delta \mathrm{ppm}: 6.87$ to 7.46 (19H, Complex), 6.44 (1H, Singlet broad). Mass $(\mathrm{m} / \mathrm{z})$ : 530. Ana. Calculated for Molecular formula $\mathrm{C}_{28} \mathrm{H}_{20} \mathrm{BrClN}_{2} \mathrm{~S}$ is $\mathrm{C} ; 63.23 \%, \mathrm{H} ; 3.79 \%, \mathrm{~N} ; 5.27 \%$ Found C; 63.20\%, H; 3.75\%, N; 5.22\%.

\subsection{4. $\mathrm{N}-((2-$ chlorophenyl $)$ diphenylmethyl $)-4-(4-$ nitrophenyl)thiazol-2-amine (KJB-4)}

Yellow Solid, Rf value 0.45 (Ethyl acetate 8: Hexane 2). IR (KBr pallet) in $\mathrm{cm}^{-1}: 3167,3026,2886,2792,2708$, 1511, 1392, 1327, 1272, 1179, 1077, 1025, 912, 846, $745,696 \mathrm{~cm}^{-1} .{ }^{1} \mathrm{H}$ NMR (DMSO) in $\delta \mathrm{ppm}: 6.88$ to 7.52 (19H, Complex), 5.44 (1H, Singlet broad). Mass $(\mathrm{m} / \mathrm{z})$ : 497. Ana. Calculated for Molecular formula $\mathrm{C}_{28} \mathrm{H}_{20} \mathrm{ClN}_{3} \mathrm{O}_{2} \mathrm{Sis} \mathrm{C} ; 67.53 \%, \mathrm{H} ; 4.05 \%, \mathrm{~N} ; 7.44 \%$ Found $\mathrm{C} ; 67.50 \%, \mathrm{H} ; 4.07 \%, \mathrm{~N} ; 7.46 \%$.

\subsection{5. $\mathrm{N}-((2-$ chlorophenyl $)$ diphenylmethyl $)-4-\left(p^{-}\right.$ tolyl)thiazol-2-amine (KJB-5)}

Yellow Solid, Rf value 0.46 (Ethyl acetate 8: Hexane 2). IR (KBr pallet) in $\mathrm{cm}^{-1}: 3122,3028,2884,2791,2709$, 1510, 1391, 1325, 1271, 1178, 1075, 1021, 911, 845, $742,692 \mathrm{~cm}^{-1} .{ }^{1} \mathrm{H}$ NMR (DMSO) in $\delta \mathrm{ppm}: 6.55$ to $7.51(19 \mathrm{H}$, Complex), 5.02 (1H, Singlet broad). Mass $(\mathrm{m} / \mathrm{z})$ : 466. Ana. Calculated for Molecular formula $\mathrm{C}_{29} \mathrm{H}_{23} \mathrm{ClN}_{2} \mathrm{~S}$ is $\mathrm{C}$; $54.58 \%, \mathrm{H} ; 4.96 \%, \mathrm{~N} ; 6.00 \%$ Found C; $54.50 \%, \mathrm{H} ; 4.95 \%$, N; 6.02\%.

\subsection{6. $\mathrm{N}-((2-c h l o r o p h e n y l)$ diphenylmethyl $)-4-(4-$ methoxyphenyl)thiazol-2-amine (KJB-6)}

Yellow Solid, Rf value 0.44 (Ethyl acetate 8: Hexane 2). IR ( $\mathrm{KBr}$ pallet) in $\mathrm{cm}^{-1}: 3112,3029,2852,2745,2708$, 1512, 1390, 1324, 1272, 1177, 1074, 1022, 910, 844, $741,691 \mathrm{~cm}^{-1} .{ }^{1} \mathrm{H}$ NMR (DMSO) in $\delta \mathrm{ppm}: 6.56$ to 7.50 (19H, Complex), 5.01 (1H, Singlet broad). Mass $(\mathrm{m} / \mathrm{z})$ : 482. Ana. Calculated for Molecular formula $\mathrm{C}_{29} \mathrm{H}_{23} \mathrm{ClN}_{2} \mathrm{OS}$ is $\mathrm{C} ; 72.11 \%, \mathrm{H} ; 4.80 \%, \mathrm{~N} ; 5.80 \%$ Found $\mathrm{C} ; 72.10 \%, \mathrm{H} ; 4.82 \%, \mathrm{~N} ; 5.82 \%$.

\subsubsection{4-(2-(((2-chlorophenyl)diphenylmethyl) amino)thiazol-4-yl)benzoic acid (KJB-7)}

Yellow Solid, Rf value 0.42 (Ethyl acetate 8: Hexane 2). IR ( $\mathrm{KBr}$ pallet) in $\mathrm{cm}^{-1}: 3111,3029,2852,2745,2708$, $1720,1512,1391,1325,1272,1177,1073,1022$, $911,844,741,688 \mathrm{~cm}^{-1} .{ }^{1} \mathrm{H}$ NMR (DMSO) in $\delta \mathrm{ppm}$ : 6.56 to $7.50(19 \mathrm{H}$, Complex $), 5.01(1 \mathrm{H}$, Singlet broad), 11.02 (1H, Singlet). Mass $(\mathrm{m} / \mathrm{z})$ : 496. Ana. Calculated for Molecular formula $\mathrm{C}_{29} \mathrm{H}_{21} \mathrm{ClN}_{2} \mathrm{O}_{2} \mathrm{~S}$ is $\mathrm{C}$; $70.08 \%, \mathrm{H} ; 4.26 \%$, N; 5.64\% Found C; 70.10\%, H; $4.22 \%, \mathrm{~N} ; 5.62 \%$.

\subsubsection{Methyl 4-(2-(((2-chlorophenyl)diphenyl- methyl)amino)thiazol-4-yl)benzoate (KJB-8)}

Yellow Solid, Rf value 0.44 (Ethyl acetate 8: Hexane 2). IR (KBr pallet) in $\mathrm{cm}^{-1}$ : 3110, 3022, 2851, 2744, 2707, 1730, 1511, 1392, 1328, 1274, 1175, 1074, 1021, $912,846,742,687 \mathrm{~cm}^{-1} .{ }^{1} \mathrm{H}$ NMR (DMSO) in $\delta \mathrm{ppm}$ : 6.55 to $7.52(19 \mathrm{H}$, Complex $), 5.02(1 \mathrm{H}$, Singlet broad), 2.06 (3H, Singlet). Mass $(\mathrm{m} / \mathrm{z})$ : 510. Ana. Calculated for Molecular formula $\mathrm{C}_{30} \mathrm{H}_{23} \mathrm{ClN}_{2} \mathrm{O}_{2} \mathrm{Sis} \mathrm{C}$; $70.51 \%, \mathrm{H} ; 4.54 \%$, N; 5.48\% Found C; 70.50\%, H; $4.56 \%, \mathrm{~N} ; 5.49 \%$.

\subsubsection{4-(2-(((2-chlorophenyl) diphenylmethyl) amino)thiazol-4-yl)phenol (KJB-9)}

Yellow Solid, Rf value 0.42 (Ethyl acetate 8: Hexane 2). IR (KBr pallet) in $\mathrm{cm}^{-1}: 3112,3021,2850,2746,2705$, $1731,1510,1391,1327,1275,1176,1076,1022$, $911,845,741,684 \mathrm{~cm}^{-1} .{ }^{1} \mathrm{H}$ NMR (DMSO) in $\delta \mathrm{ppm}$ : 6.55 to $7.52(19 \mathrm{H}$, Complex $), 5.02(1 \mathrm{H}$, Singlet broad), 3.22 (1H, Singlet). Mass (m/z): 468. Ana. Calculated for Molecular formula $\mathrm{C}_{28} \mathrm{H}_{21} \mathrm{ClN}_{2} \mathrm{OSis} \mathrm{C}$; $71.71 \%, \mathrm{H} ; 4.51 \%$, N; 5.97\% Found $\mathrm{C} ; 71.70 \%, \mathrm{H}$; $4.52 \%, \mathrm{~N} ; 5.91 \%$.

\subsubsection{0. $\mathrm{N}-(4-(2-(($ (2-chlorophenyl) diphenylmethyl) amino)thiazol-4-yl)phenyl)acetamide (KJB-10) \\ Yellow Solid, Rf value 0.41 (Ethyl acetate 8: Hexane 2).}


IR (KBr pallet) in $\mathrm{cm}^{-1}: 3114,3028,2855,2742,2706$, 1640,1512 , 1390, 1325, 1274, 1175, 1075, 1021, $910,844,742,685 \mathrm{~cm}^{-1} .{ }^{1} \mathrm{H}$ NMR (DMSO) in $\delta \mathrm{ppm}$ : 6.55 to $7.85(19 \mathrm{H}$, Complex), 8.02 (1H, Singlet broad), 3.22 (1H, Singlet), 2.55 (3H, Singlet), 9.52 (1H, Singlet broad). Mass (m/z): 509. Ana. Calculated for Molecular formula $\mathrm{C}_{30} \mathrm{H}_{24} \mathrm{ClN}_{3} \mathrm{OSis} \mathrm{C} ; 70.64 \%, \mathrm{H} ; 4.74$ \%, N; 8.24\% Found C; 70.68\%, H; 4.75\%, N; 8.26\%.

\subsection{In vitro biological screening}

All novel synthesized entities were investigated for them in-vitro antibacterial activity. The BioAssay result demonstrated that compounds (01 to10) succeeded to indicate remarkable activity against below mentioned microorganism when compare to standard drugs. The result includes that KJB-3 \& $\mathbf{K J B}-\mathbf{8}$ both compound showing remarkable activity which is showed in Table 2. In KJB-3 \& KJB-8 both contain bromine group and ester group respectively. All the synthesized compound were tested for their in vitro antimicrobial activity against Gram +ve (Bacillus megaterium, Micrococcus spp.), Gram -ve (E.coli, S. typi) and fungal spps. (Ganoderma spp., A. niger, A. flavus and Penicillium spp.), taking streptomycin, ciprofloxacin, and nystatin as standard drugs.

Table1: Physical constant of synthesized library

\begin{tabular}{cccccc}
\hline Code & Molecular formula & Substitution & Molecular Weight & M.P. ${ }^{\circ} \mathbf{C}$ & Percentage Yield \\
\hline KJB-1 & $\mathrm{C}_{28} \mathrm{H}_{21} \mathrm{ClN}_{2} \mathrm{~S}$ & $-\mathrm{H}$ & 452 & $152-154$ & 88 \\
\hline KJB-2 & $\mathrm{C}_{28} \mathrm{H}_{20} \mathrm{Cl}_{2} \mathrm{~N}_{2} \mathrm{~S}$ & $-\mathrm{Cl}$ & 486 & $178-180$ & 72 \\
\hline KJB-3 & $\mathrm{C}_{28} \mathrm{H}_{20} \mathrm{BrClN}_{2} \mathrm{~S}$ & $-\mathrm{Br}$ & 530 & $146-148$ & 56 \\
\hline KJB-4 & $\mathrm{C}_{28} \mathrm{H}_{20} \mathrm{ClN}_{3} \mathrm{O}_{2} \mathrm{~S}$ & $-\mathrm{NO}_{2}$ & 497 & $164-166$ & 58 \\
\hline KJB-5 & $\mathrm{C}_{29} \mathrm{H}_{23} \mathrm{ClN}_{2} \mathrm{~S}$ & $-\mathrm{Me}$ & 466 & $168-170$ & 56 \\
\hline KJB-6 & $\mathrm{C}_{29} \mathrm{H}_{23} \mathrm{ClN}_{2} \mathrm{OS}$ & $-\mathrm{OMe}$ & 482 & $154-156$ & 72 \\
\hline KJB-7 & $\mathrm{C}_{29} \mathrm{H}_{21} \mathrm{ClN}_{2} \mathrm{O}_{2} \mathrm{~S}$ & $-\mathrm{COOH}$ & 496 & $184-186$ & 58 \\
\hline KJB-8 & $\mathrm{C}_{30} \mathrm{H}_{23} \mathrm{ClN}_{2} \mathrm{O}_{2} \mathrm{~S}$ & $-\mathrm{COOR}$ & 510 & $146-148$ & 70 \\
\hline KJB-9 & $\mathrm{C}_{28} \mathrm{H}_{21} \mathrm{ClN}_{2} \mathrm{OS}$ & $-\mathrm{OH}$ & 468 & $182-184$ & 56 \\
\hline KJB-10 & $\mathrm{C}_{30} \mathrm{H}_{24} \mathrm{ClN}_{3} \mathrm{OS}$ & $-\mathrm{NHCOMe}$ & 509 & $186-188$ & 62 \\
\hline
\end{tabular}

Table 2: Biological results of synthesized compounds

\begin{tabular}{|c|c|c|c|c|c|c|c|c|}
\hline \multirow{4}{*}{ Code } & \multicolumn{4}{|c|}{ Antibacterial activity } & \multicolumn{4}{|c|}{ Antifungal activity } \\
\hline & \multicolumn{4}{|c|}{$\begin{array}{c}\text { Antibacterial activity (zone in } \mathrm{cm}), \\
\text { concentration: } 1 \mathrm{mg} / \mathrm{ml} .\end{array}$} & \multirow{2}{*}{\multicolumn{4}{|c|}{$\begin{array}{l}\text { Antifungal activity (zone in } \mathrm{cm}), \\
\text { concentration: } 1 \mathrm{mg} / \mathrm{ml}\end{array}$}} \\
\hline & \multicolumn{2}{|c|}{ Gram +ve bacteria } & \multicolumn{2}{|c|}{$\begin{array}{l}\text { Gram-ve } \\
\text { bacteria }\end{array}$} & & & & \\
\hline & $\begin{array}{c}\text { B. } \\
\text { megaterium }\end{array}$ & $\begin{array}{l}\text { Micrococcus } \\
\text { spp. }\end{array}$ & $\begin{array}{c}S . \\
\text { typhi. }\end{array}$ & $\begin{array}{c}E . \\
\text { coli. }\end{array}$ & $\begin{array}{l}\text { Penicillium } \\
\text { spp. }\end{array}$ & $\begin{array}{l}\text { Ganoderma } \\
\text { spp. }\end{array}$ & $\begin{array}{c}\text { A. } \\
\text { niger }\end{array}$ & A. flavus \\
\hline 01 & 1.0 & 1.6 & 1.9 & - & 1.2 & 1.1 & 0.8 & 0.2 \\
\hline 02 & 1.4 & 1.4 & - & - & 2.0 & 2.2 & 2.8 & 2.1 \\
\hline 03 & 2.4 & 3.2 & 2.0 & 2.1 & 2.1 & 2.6 & 2.1 & 3.2 \\
\hline 04 & 1.8 & 1.9 & 1.6 & 1.0 & 0.8 & 1.2 & 0.8 & - \\
\hline 05 & - & - & 1.4 & 1.2 & 0.8 & 2.8 & 0.8 & 0.5 \\
\hline 06 & 0.9 & 1.2 & 1.2 & 1.2 & - & 1.2 & - & 0.9 \\
\hline 07 & 1.4 & 2.2 & 1.7 & - & 0.1 & 1.8 & 2.6 & 1.9 \\
\hline 08 & 2.3 & 2.7 & 1.7 & 2.2 & 1.4 & 2.6 & 2.0 & 1.8 \\
\hline 09 & - & 1.7 & 1.2 & 1.8 & 0.6 & 0.8 & 1.6 & - \\
\hline 10 & 1.4 & - & 1.3 & 1.0 & 2.1 & - & 2.0 & 2.7 \\
\hline $\begin{array}{l}\text { Streptomycin } \\
(200 \mu \mathrm{g} / \mathrm{ml})\end{array}$ & 3.0 & 2 & 2 & 3.2 & - & - & - & - \\
\hline $\begin{array}{l}\text { Ciprofloxacin } \\
(200 \mu \mathrm{g} / \mathrm{ml})\end{array}$ & 3.8 & 4 & 4 & 3 & - & - & - & - \\
\hline $\begin{array}{l}\text { Nystatin } \\
(200 \mu \mathrm{g} / \mathrm{ml})\end{array}$ & - & - & - & - & 3.2 & 4 & 3.5 & 3.8 \\
\hline
\end{tabular}




\section{CONCLUSION}

We have demonstrated the synthesis of a novel class of substitute $\mathrm{N}$-((2-chlorophenyl)diphenylmethyl)-4phenylthiazol-2-amine. Overall the reaction was carried out clean and the products were obtained in excellent yields without any further formation of any side products or purification needed. Total ten compounds were synthesized and structure of all of them was confirmed on the basis of the spectroscopic techniques. The present work is important for the synthesis of a wide variety of novel entities. The result includes that KJB-3 \& KJB-8 exhibited potent antibacterial activity against B. megaterium, S. typi, Micrococcus spp. and E.coli hence further investigation can be done, MIC can be identified and such compounds can further be tested and can be used as a potent drug.

\section{Conflict of interst}

None declared

\section{REFERENCES}

1. Oh H, Cho HW, Baek D, Cho JH. European Journal of Medicinal Chemistry, 2002; 37:743-754.

2. Tapia RA, Prieto Y, Pautet F. Bioorganic and Medicinal Chemistry, 2003; 11:3407-3412.

3. Suresh Kumar GV, Rajendraprasad Y, Mallikarjuna BP, Chandrashekar SM, Kistayya C. European Journal of Medicinal Chemistry, 2010; 45:2063-2074.

4. Samadhiya P, Sharma R, Srivastava SK, Srivastava SD. Journal of the Serbian Chemical Society, 2012;77:599-605.

5. Sonwane SK, Srivastava SD. National Academy of Sciences, India, 2008; 78:129-136.

6. Srivastava SK, Yadav R, Srivastava SD, Indian Journal of Chemistry, 2004; 43B:399-405.

7. Ghaemmaghami S, May BCH, Renslo AR, Prusiner SB. Journal of Virology, 2010; 84(7):3408-3412.

8. Siddiqui HL, Zia-Ur-Rehman M, Ahmad N, Weaver GW, Lucas PD. Chemical and Pharmaceutical Bulletin, 2007; 55(7):1014-1017.

9. Kesicki EA, Bailey MA, Ovechkina Y et al. PLOS ONE, 2016; 11(5):5.

10. Lin P, Hou R, Wang H, Kang I, Chen L. Journal of the Chinese Chemical Society, 2009; 56(3):455-458.

11. Gorczynski MJ, Leal RM, Mooberry SL, Bushweller JH, Brown ML. Bioorganic and Medicinal Chemistry, 2004; 12(5):1029-1036.
12. Misra RN, Xiao HY, Williams DK et al. Bioorganic and Medicinal Chemistry Letters, 2004; 14(11):29732977.

13. El-Subbagh HI, Abadi AH, Lehmann J. Archiv der Pharmazie, 1999; 332(4):137-142.

14. Kayagil I, Demirayak S, Phosphorus Sulfur and Silicon and the Related Elements, 2009; 184(9):2197-2207.

15. Priyanka, Neeraj KS, Keshari KJ. International Journal of Current Pharmaceutical Research, 2010; 2:16.

16. Singh HP, Sharma CS, Gautam CP. AmericanEurasian Journal of Scientific Research, 2009; 4(4):222-228.

17. Kaur H, Kumar S, Singh I, Saxena KK, Kumar A. Digest Journal of Nano- materials \& Biostructures, 2010; 5(1):67-76.

18. Chavan AA, Pai NR. Molecules 2007; 12(11):24672477.

19. Nadeem S, Arpana R, Suroor AK. Acta Pharmaceutica, 2009; 59(4):441-451.

20. Masoudi NA, Pfleiderer W, Pannecouque C. ZeitschriftfürNaturforschung B，2014； 67(8):835842.

21. Gajdo SP, Magdolen P, Zahradn'sk P, Folt'ınova P, Molecules 2009; 14(12):5382-5388.

22. Gill RK, Rawal RK, Bariwal J. Archiv der Pharmazie, 2015; 348(3):155-178.

23. Paramashivappa R, Phani Kumar P, SubbaRao PV, Srinivasa Rao A. Bioorg. Med. Chem. Lett, 2003; 13: 657.

24. Shashank D, Vishawanth T, Arif Pasha M. International Journal of ChemTech Researchvol, 2009; 4:1224-1231.

25. Papadopoulou C, Geronikaki A, HadjipavlouLitina D, Farmaco, 2005; 60(11-12):969-973,

26. Theophil E, Siegfried H, The Chemistry of Heterocycles Structure: Reactions, Syntheses, and Applications, Wiley-VCH, Verlag $\mathrm{GmbH}$, and Co., Weinheim, Germany, 2nd edition, 2003.

27. Dawane BS, Konda SG, Kamble VT, Chavan SA, Bhosale RB, Shaikh BM. E-Journal of Chemistry, 2009; 6(1):S358-S362.

28. Lednicer D, Mitscher LA, Georg GI. Organic Chemistry of Drug Synthesis, vol. 4, John Wiley \&amp; Sons, Inc., New York, NY, USA, 1990.

29. Kim KS, Kimball SD, Misra RN, Rawlins DB. J. Med. Chem, 2002; 45(18):3905-3927. 